\title{
Intestinal Coccidia (Apicomplexa: Eimeriidae) of Brazilian Lizards. Eimeria carmelinoi n.sp., from Kentropyx calcarata and Acroeimeria paraensis n.sp. from Cnemidophorus lemniscatus lemniscatus (Lacertilia: Teiidae)
}

\author{
Ralph Lainson
}

Departamento de Parasitologia, Instituto Evandro Chagas, Avenida Almirante Barroso 492, 66090-000 Belém, PA, Brasil

Eimeria carmelinoi $n . s p$. , is described in the teiid lizard Kentropyx calcarata Spix, 1825 from north Brazil. Oocysts subspherical to spherical, averaging $21.25 \times 20.15 \mu \mathrm{m}$. Oocyst wall smooth, colourless and devoid of striae or micropyle. No polar body or conspicuous oocystic residuum, but frequently a small number of fine granules in Brownian movement. Sporocysts, averaging $10.1 \times 9 \mu \mathrm{m}$, are without a Stieda body. Endogenous stages characteristic of the genus: intra-cytoplasmic, within the epithelial cells of the ileum and above the host cell nucleus. A redescription is given of a parasite previously described as Eimeria cnemidophori, in the teiid lizard Cnemidophorus lemniscatus lemniscatus. A study of the endogenous stages in the ileum necessitates renaming this coccidian as Acroeimeria cnemidophori (Carini, 1941) nov.comb., and suggests that Acroeimeria pintoi Lainson \& Paperna, 1999 in the teiid Ameiva ameiva is a synonym of A. cnemidophori. A further intestinal coccidian, Acroeimeria paraensis n.sp. is described in C. 1. lemniscatus, frequently as a mixed infection with A. cnemidophori. Mature oocysts, averaging $24.4 \times 21.8 \mu \mathrm{m}$, have a single-layered, smooth, colourless wall with no micropyle or striae. No polar body, but the frequent presence of a small number of fine granules exhibiting Brownian movements. Sporocysts $9 \times 8$, without a Stieda body. Endogenous stages epicytoplasmic, characteristic of the genus, in the upper ileum. The importance of a study of the endogenous stages of eimeriid coccidia is discussed.

Key words: Apicomplexa - Eimeriidae - Eimeria carmelinoi n.sp. - Acroeimeria paraensis n.sp. - Acroeimeria cnemidophori (Carini, 1941) nov.comb. - endogenous stages - Kentropyx calcarata - Cnemidophorus lemniscatus - lizards - Brazil

Many of the recorded Eimeria species of reptiles (Levine 1988) have their inclusion in the genus based solely on the morphology of their mature oocysts and sporocysts, following the classic "Periodic Table" of Hoare (1956) updated by Levine (1973), and with no consideration for any differences that might exist in the rest of the parasites' life-cycle. An understanding of the complete life-cycle of protozoal parasites is fundamental, however, in allocating them to their correct genus and species. Thus, elucidation of the complex life-cycles of members of the family Sarcocystidae enables separation of genera such as Toxoplasma, Sarcocystis, Besnoitia, Frenkelia and Hammondia which produce oocysts and sporocysts that are morphologically very similar, if not indistinguishable (Dubey 1977), and the mode of development of the endogenous stages of some Old and New World species of reptilian Isospora separates parasites which cannot reliably be identified by morphology of the oocysts alone (Finkelman \& Paperna 1994, Lainson \& Paperna 1999b).

Bovee and Telford (1965) described a peculiar development of the endogenous stages of a coccidian in spe-

Work supported by grant 049426 from the Wellcome Trust, London.

Fax: + 55-91-226.1284. E-mail: lainson@ iec.pa.gov.br

Received 6 July 2001

Accepted 3 August 2001 cies of the iguanid lizard Sceloporus in which the parasites formed a layer on the surface of the gut epithelium, to which they were carried by a stalk-like growth of the extruded host cells. They attached no taxonomic importance to this curious departure from the normal intracytoplasmic development of Eimeria, however, and followed the common practise of placing all tetrasporocystic, dizoic oocysts in that genus by naming the parasite E. sceloporis.

Impressed by the occurrence of this type of development in the life-cycle of some other reptilian coccidia with Eimeria-like oocysts, Paperna and Landsberg (1989) used it to erect two new generic names. One of these, Acroeimeria, contains those parasites which inicially develop immediately beneath the brush-border of the intestinal epithelium, but the meronts and gamonts of which are early on extruded to form a layer on the surface of the gut mucosa (Figs 32, 33). Other parasites undergoing a similar development in the epithelium of the gall-bladder were placed in the genus Choleoeimeria. The oocysts of both genera possess four sporocysts, each containing two sporozoites, like those of Eimeria. In their study of coccidia of the gecko Hemidactylus turcicus from Israel, Paperna and Landsberg (1989) concluded that the parasite described as E. lineri by McAllister et al. (1988) in the same species of gecko introduced into North America, should be renamed as $A$. lineri, based on its epicytoplasmic development in the intestine, and further suggested the replacement name of A. sceloporis (Bovee $\&$ Telford 1965) n.comb., for the parasite of Sceloporus from North and Central America. 
Lainson and Paperna (1999a) described C. carinii and A. pintoi in the gall-bladder and intestine, respectively, of the Brazilian lizard Ameiva ameiva, and renamed the parasite previously described as E. rochalimai, in the gecko H. mabouia, as C. rochalimai (Carini and Pinto 1926). The same authors (Paperna \& Lainson 1999) have presented ultrastructural evidence supporting separation of the reptilian coccidia producing tetrasporocystic, dizoic oocysts into the genera Eimeria s.l., Acroeimeria and Choleoeimeria.

The present paper follows this taxonomy in descriptions of the mature oocysts and endogenous development of E. carmelinoi n.sp. in the teiid lizard Kentropyx calcarata and A. paraensis n.sp. in the teiid Cnemidophorus lemniscatus lemniscatus. A redescription is given of the oocysts of a parasite originally described under the name of E. cnemidophori (Carini 1941) in C. l. lemniscatus. Following a study of the endogenous stages in the intestine, the parasite is renamed A. cnemidophori (Carini 1941) nov.comb.

\section{MATERIALS AND METHODS}

Specimens of $K$. calcarata were captured by hand in low, varzea-type forest clearings on the island of Outeiro, near Icoaraci, Pará, North Brazil ( $1^{\circ} 18^{\prime} \mathrm{S}$ : $\left.48^{\circ} 27^{\prime} \mathrm{W}\right)$. Those of $C$. l. lemniscatus were from an open, sandy habitat in Capanema, Pará $\left(1^{\circ} 12^{\prime} S: 47^{\circ} 1^{\prime} \mathrm{W}\right)$.

The lizards were maintained separately in plastic mouse cages, on a diet of Tenebrio larvae. Faecal samples were suspended in a small quantity of $2 \%$ aqueous potassium dichromate solution $\left(\mathrm{K}_{2} \mathrm{Cr}_{2} \mathrm{O}_{7}\right)$, kept as thin layers in Petri dishes, and examined for coccidial oocysts using normal light microscopy with $\mathrm{x} 16$ and $\mathrm{x} 40$ objectives and $\mathrm{x} 10$ eyepieces. Positive samples were checked repeatedly to establish the sporulation time of oocysts. All measurements were made using an eyepiece micrometer and the oil immersion lens. They are given, in $\mu \mathrm{m}$, as the means of 50 oocysts and 50 sporocysts, followed by the range in parentheses and the shape index (ratio of length/ width). Photomicrographs were made with a Zeiss "Photomicroscope III" and Kodak TMX 100 film.

The more heavily infected lizards were killed with chloroform and the site and mode of development of the coccidians ascertained by the examination of bile removed from the gall-bladder with a finely drawn out glass pipette, and scrapings of the intestinal epithelium throughout its length. The intestine was divided into four portions and one longitudinal half of each piece fixed in $10 \%$ neutral formol-saline or Carnoy's fluid for histology. The other halves were used to make smears of the intestinal epithelium. Some smears were air-dried, fixed in absolute methyl alcohol and stained by Giemsa's method for $1 \mathrm{~h}$; others were fixed in aqueous Bouin's fluid for $20 \mathrm{~m}$, washed in $70 \%$ ethyl alcohol until colourless, stained by the same method and then differentiated in a graded series of acetone/xylol mixtures from 95:5 down to pure xylol, for subsequent mounting under cover-slips in "Permount".

\section{RESULTS}

Of $22 \mathrm{~K}$. calcarata examined, $5(22.7 \%)$ showed coccidial oocysts of a single morphological type in the faeces.
Endogenous stages were abundant in the upper part of the ileum and the parasite identified as a previously unrecorded species of Eimeria, described below. No parasites were detected in the gall-bladder contents,

Of 42 specimens of $C$. l. lemniscatus examined, 13 (30.9\%) showed oocysts in the faeces. These were of two types, occurring as single infections in some animals and mixed infections in others. The morphology of the smaller oocyst corresponded closely to that described as E. cnemidophori by Carini (1941) in the same lizard, but the endogenous development is clearly that of Acroeimeria. In the following description the parasite is therefore referred to as A. cnemidophori (Carini 1941) nov. comb. No oocysts could be detected in the gall-bladder contents. The second, larger oocyst in C. l. lemniscatus is probably that mentioned, but not described, by Carini (1941). It is considered to represent a new species, described below as A. paraensis, based on a study of the endogenous stages studied in the ileum of 7 lizards showing only the larger oocysts in their faeces.

\section{Eimeria carmelinoi n.sp.}

(Figs 1-23; 51)

Description of the oocyst: mature forms $21.2 \times 20.1$ (20 x18.5-23 x 21.5), shape-index 1 (1-1.1), spherical to subspherical (Figs 16-18, 51). Oocyst wall a single, smooth colourless layer about 1.0 thick and devoid of micropyle or striations (pores). No conspicuous oocyst residuum or polar body, but occasional presence of a small number of tiny granules which are usually in Brownian movement. Sporocysts 10.1 x $9(9.6$ x 8.8-11.8 x 11.1), shape-index 1.1 (1-1.1): no Stieda body or other localized thickening of the wall, which is readily deformed. Sporozoites with at least one refractile body and curving gently around a bulky sporocystic residuum of fine granules.

Endogenous stages: intracytoplasmic in the epithelial cells of the ileum, and located above the host cell nucleus (Fig. 23). Meronts reaching up to 20 in diameter as seen in stained impression smears (Figs 1-3) and about 10 in histological sections (Figs 19, 20). They produce from 6 to 20 merozoites of at least two different sizes, averaging $8 \times 3$ (Figs 4,5) and 6 x 1.5 (Fig. 6). The cytoplasm of the developing meronts contains a steadily increasing number of conspicuous, spherical vacuoles with a distinct "punched-out" appearance. Youngest macrogamonts seen in stained smears measure approximately $4 \times 3$ (Fig. 7). They are round to ovoid and soon develop small vacuoles, of variable size, and intensely staining precursers of the wall-forming bodies (Figs 7,8). The nucleus is diffuse and seen with difficulty. Macrogamonts measuring 25 in smears (Fig. 10) and about 15 in sections (Fig. 20) contain abundant large, intensely staining wall-forming bodies. Young microgamonts (Figs 11,12 ) are readily differentiated from the immature asexual stages by their intensely staining and irregular or comma-shaped nuclei. With growth, numerous spherical vacuoles appear in the cytoplasm, similar to those seen in the meronts and young macrogamonts. In sections the nuclei are seen to be arranged peripherally at the surface of the parasite (Fig. 21). Mature forms, shedding microgametes, measure from 15- 30 in diameter, as seen in stained smears (Figs 13,15), and produce a very large number of 


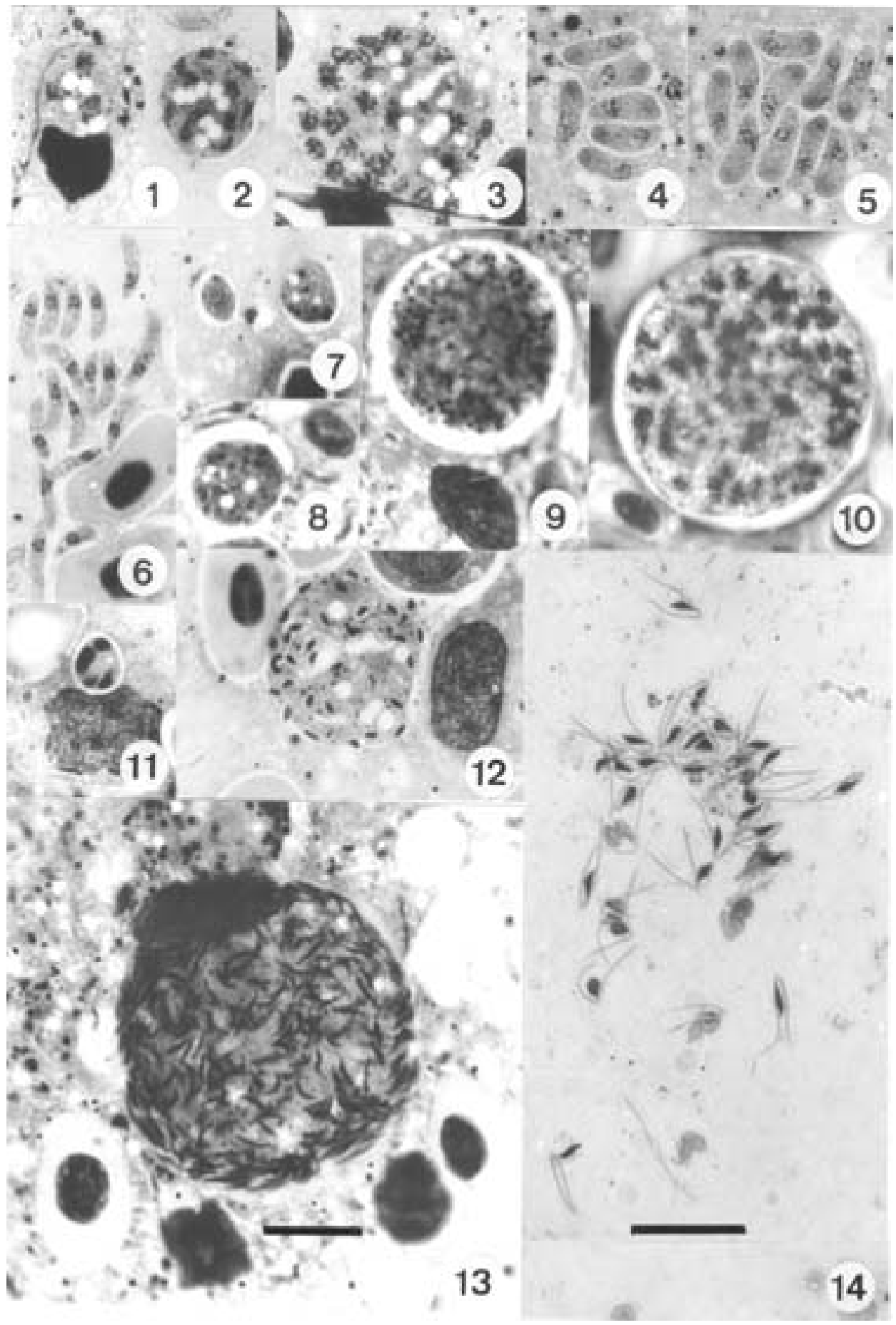

Figs 1-14: endogenous stages of Eimeria carmelinoi n.sp., in smears of the small intestine of the lizard Kentropyx calcarata. Figs 1-3: developing meronts. Figs 4, 5: segmented meronts producing 6 and 10 large merozoites. Fig. 6: segmented meront producing 18 smaller merozoites. Figs 7-9: young macrogamonts, showing conspicuous vacuoles and precursers of the wall-forming bodies. Fig. 10: mature macrogamont with large, densely staining wall-forming bodies. Figs 11, 12: young microgamonts. Fig. 13: mature microgamont with fully developed microgametes. Fig. 14: biflagellated microgametes from a ruptured microgamont. Figs 1-13: Bouin-fixed, Giemsa staining; bar $=10 \mu \mathrm{m}$. Fig. 14: methyl alcohol fixation, Giemsa staining; bar $=10 \mu \mathrm{m}$ 


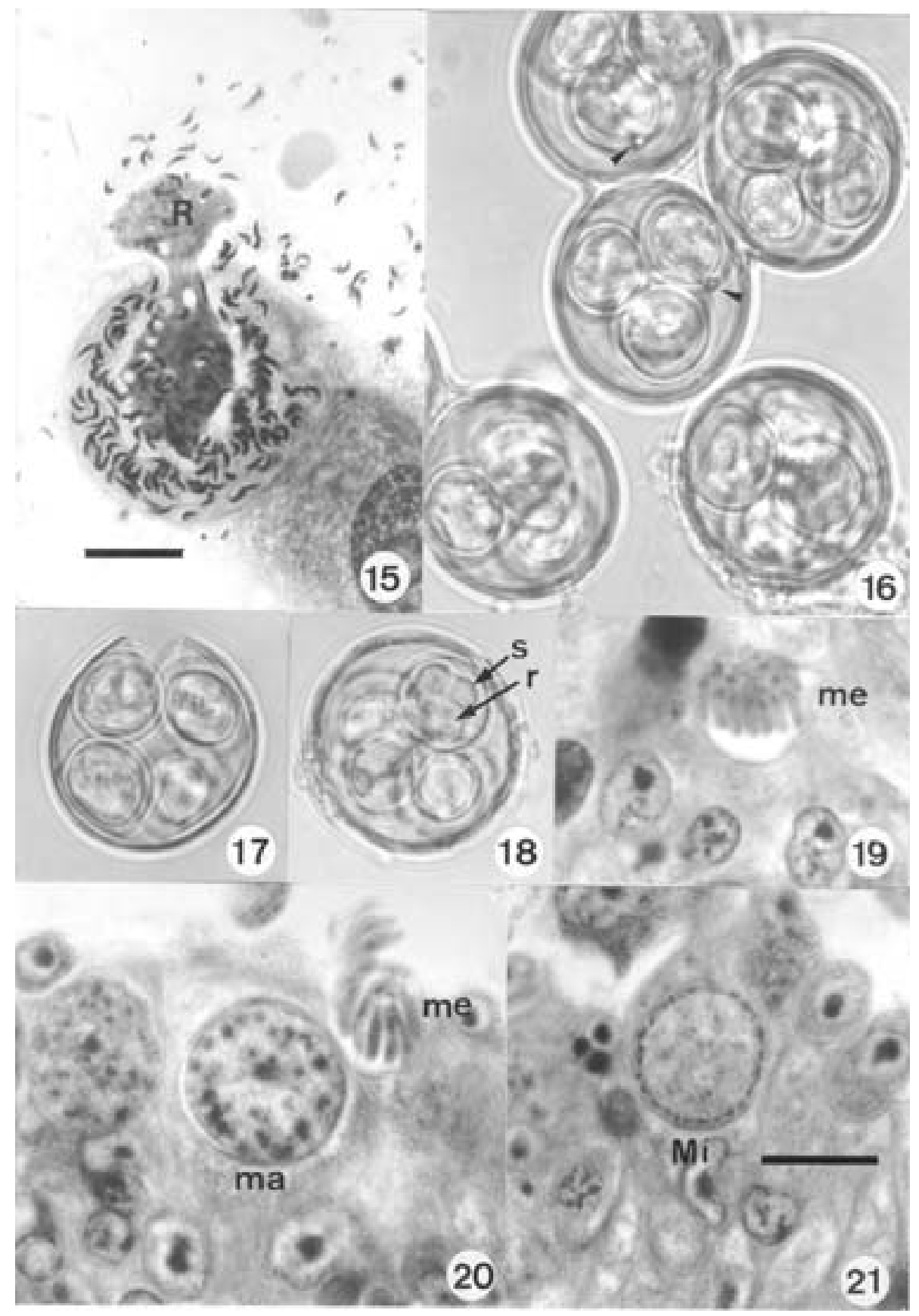

Figs 15-21: Eimeria carmelinoi n.sp., in the lizard Kentropyx calcarata. Fig. 15: mature microgamont in a Bouin-fixed, Giemsa-stained smear of the small intestine. Note the conspicuous residuum (R) and failure of the flagella to stain following this method of fixation. Bar $=10 \mu \mathrm{m}$ and also applies to Figs 16-18. Figs 16-18: mature oocysts in the faeces. Arrow-heads show the tiny granules frequently present in the oocysts, and a ruptured oocyst (Fig. 17) shows the wall to be of a single layer. Figs 19-21: histological sections of the ileum, showing mature meronts (me), a mature macrogamont (ma) and an immature microgamont (Mi) with peripherally disposed nuclei. Carnoy fixation, Giemsa stain, bar $=10 \mu \mathrm{m}$ 
biflagellate microgametes of approximately $3 \times 1$ (Fig. 14). There remains a prominent residuum (Fig. 15).

Sporulation: exogenous, within $18 \mathrm{~h}$ outside the host

Type host: the lizard Kentropyx calcarata Spix, 1825 (Lacertilia: Teiidae)

Type locality: varzea-type forest clearings on the island of Outeiro, near Icoaraci, State of Pará, North Brazil ( $1^{\circ} 18^{\prime} \mathrm{S}$ : $\left.48^{\circ} 27^{\prime} \mathrm{W}\right)$.

Prevalence: of 22 animals examined, 5 were infected (22.7\%)

Pathology: outwardly, all infected lizards appeared in good health, including those with very large numbers of oocysts in the faeces

Etymology: the specific name is given in appreciation of the 36 years dedicated service given by Mr Manoel Carmelino de Souza in the author's laboratory

Type material: stained smears and sections of endogenous stages in the author's collection, Department of Parasitology, Instituto Evandro Chagas. Reference number 1763

Acroeimeria cnemidophori (Carini, 1941) nov.comb. (Figs 24-41; 52)

Re-description of the oocyst: mature forms 18.4 x $17.6(15$ $\mathrm{x} 15-20 \mathrm{x} 18.75)$, shape-index 1 (1- 1.1), spherical to subspherical (Figs 40, 41, 52). Oocyst wall smooth colourless and apparently of a single layer 0.5-1 thick: no micropyle or striations. No oocyst residuum, but occasionally a single polar body of about $1-2$. Sporocysts 8.1 x $7.3(6.8 \times 6.2-8.7 \times 7.5)$, shape-index 1.1 (1-1.3), with no Stieda body or other localized thickening of the wall: sporozoites slightly curved about a bulky sporocystic residuum of fine granules. Presence of refractile bodies unconfirmed. In newly matured oocysts the sporozoites undergo considerable movement within the sporocyst.

Endogenous stages: these are in the ileum. Development of both meronts and gamonts is iniciated immediately beneath the brush border of the epithelial cells, but the host cells are soon displaced to the lumen of the intestine, so that the parasites form a layer on the surface of the epithelium. Below the parasitophorous vacuole containing the parasite, the host cell cytoplasm expands as the volume of the parasite increases, giving rise to a stalk-like structure, sometimes still apparent when the parasite is fully developed (Figs 38, 39). Most frequently, however, no trace remains of the host cell and the parasites appear to be extracellular on the surface of the gut epithelium (Figs 32,33). Meronts seen in section measured about 10 in diameter and produced up to 20 merozoites: these are budded off from a basal residuum, giving the appearance of a hand of bananas (Figs 34, 35, 37): in stained smears the crescentic merozoites measured approximately $8 \times 2.5$ (Fig. 25). In young macrogamonts the wall-forming bodies appear to arise in association with a collection of small vacoules (Fig. 26) and with growth of the parasite they increase greatly in size and number (Figs 27,28). In stained smears the largest forms seen reached about 20 in diameter. In sections of material fixed in Carnoy's fluid they were from 17-20 in diameter and the wall-forming bodies stained poorly (Figs $33,34,36$ ). Sectioned zygotes, or early oocysts, measured 16 x 15 .
Development of the microgamont follows the usual eimeriid pattern (Figs 29-31); the mature forms shed a very large number of biflagellate microgametes measuring approximately $4-5 \times 0.5$ and leave a bulky cytoplasmic residuum. In sections the fully developed male parasites were about the same size as the mature macrogamonts (Fig. 39).

Sporulation: exogenous, within $14 \mathrm{~h}$ in newly voided faeces

Type host: the lizard Cnemidophorus l. lemniscatus (Lacertilia: Teiidae)

Type locality: the infected lizards studied by Carini (1941) were from Porto Nacional, State of Goiás, West Central Brazil (10 $42^{\prime} \mathrm{S}$ : $\left.48^{\circ} 25^{\prime} \mathrm{W}\right)$. Material for the present redescription is from lizards collected in Capanema, State of Pará, North Brazil ( $\left.1^{\circ} 12^{\prime} \mathrm{S}: 47^{\circ} 11^{\prime} \mathrm{W}\right)$

Prevalence: in the present study, $10 \mathrm{C}$. l. lemniscatus were infected (23.8\%). Of these, 8 were mixed infections with A. paraensis n.sp., (see below)

Pathology: lizards appeared to be unaffected by the infection, even when passing enormous numbers of oocysts (Fig. 40)

Type material: that of Carini (1941) is presumably not available. Stained smears and sections of endogenous stages of the Capanema material in the author's collection, Department of Parasitology, Instituto Evandro Chagas: Reference number 1839 .

\section{Acroeimeria paraensis n.sp.} (Figs 42-49; 53)

Description of the oocyst: mature forms 24.4 × $22(22.5 \times 19$ $27.5 \times 25$ ), shape-index 1.1 (1-1.2), broadly ellipsoidal, occasionally spherical to subspherical (Figs 49, 53). Oocyst wall a single-layered, smooth colourless layer about 0.5-1 thick, with no micropyle or striae. No conspicuous oocystic residuum, but the frequent presence of a variable number of fine granules in Brownian movement. Sporocysts $9 \times 8$ (8.7 x 7.5 - 12.5 x 9), shape-index 1.1 (1-1.4), with no Stieda body or other localized thickening of the wall which is frequently deformed in the older oocysts. Presence of refractile bodies not confirmed: sporozoites gently curved about a bulky sporocyst residuum of fine granules.

Endogenous stages: in the upper half of the ileum. Epicytoplasmic development, as described for the genus. The only mature meronts seen were small; as seen in sections (Fig. 46), they measured from 10-12 in diameter and produced from 10-14 merozoites which are strongly crescentic and measure about $6 \times 1.5$ (Fig. 42). Young macrogamonts, measuring from $6 \times 5-10 \times 8$, early on possess a clump of wall-forming body precursers frequently associated with a variable number of cytoplasmic vacuoles (Fig. 43). Macrogamonts measuring up to 25, as seen in smears and sections, contain large numbers of densely staining wall-forming bodies (Fig. 44). In sections the fully developed microgamonts measured up to 18 in diameter and produced a large number of microgametes (Fig. 48).

Sporulation: exogenous, within $20 \mathrm{~h}$ outside the host Type host: the lizard Cnemidophorus l. lemniscatus (Lacertilia: Teiidae) 


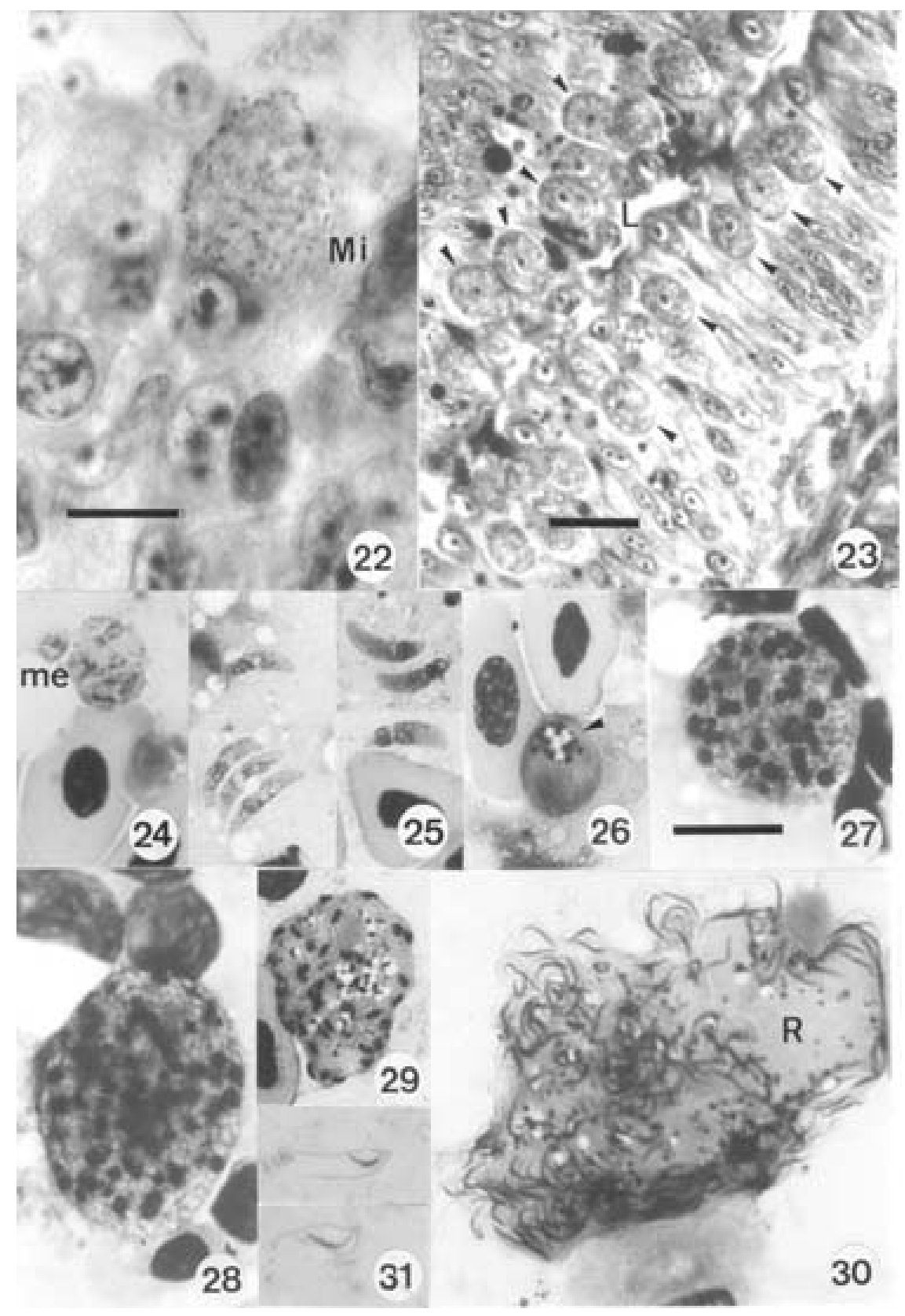

Figs 22, 23: Eimeria carmelinoi n.sp. in the lizard Kentropyx calcarata. Histological sections of the ileum, Carnoy fixation, Giemsa staining. Fig. 22: an almost mature microgamont $(\mathrm{Mi})$; bar $=10 \mu \mathrm{m}$. Fig. 23: low power view showing large number of intracytoplasmic macrogamonts (arrow-heads) in the epithelial cells; bar $=20 \mu \mathrm{m}$; L: gut lumen. Figs 24-30: Acroeimeria cnemidophori of the teiid lizard Cnemidophorus lemniscatus lemniscatus in a Bouin-fixed, Giemsa-stained smear of the ileum. Fig. 24: young meronts (me). Fig. 25: merozoites. Fig. 26: very young macrogamont, showing precursers of wall-forming bodies associated with cytoplasmic vacuoles (arrowhead). Figs 27, 28: developing and mature macrogamonts, with large wall-forming bodies. Fig. 29: developing microgamont. Fig. 30: mature microgamont shedding biflagellated microgametes (Fig. 31); bar in Fig. $27=10 \mu \mathrm{m}$ and applies to Figs 24-30; R: residuum 


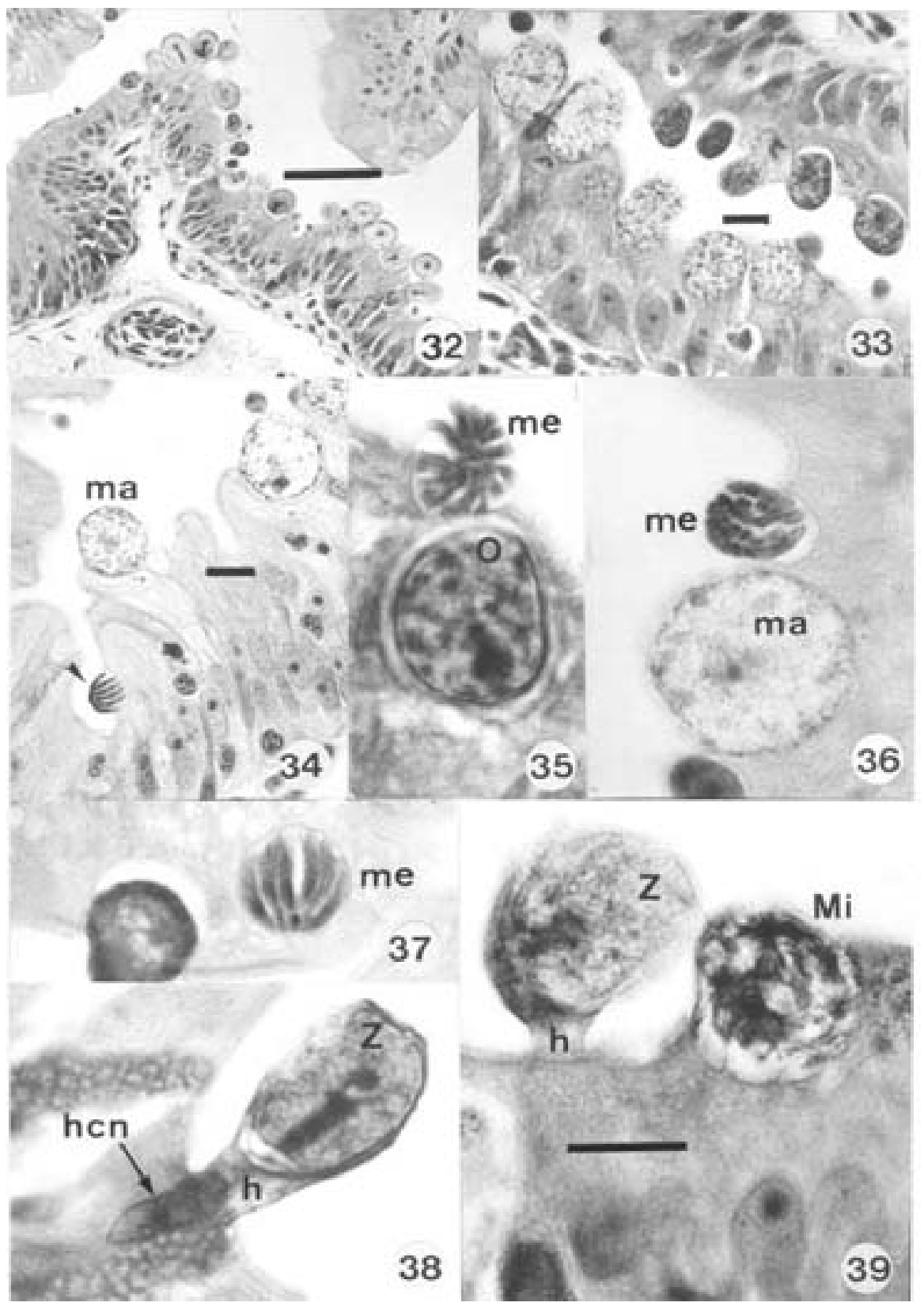

Figs 32-39: Acroeimeria cnemidophori in the teiid lizard Cnemidophorus lemniscatus lemniscatus. Figs 32-34: low power view of ileum sections, showing layer of developing and mature parasites, mostly macrogamonts, and a segmented meront (arrow-head, Fig. 34) on gut surface; Carnoy/Giemsa; bar in Fig. $32=50 \mu \mathrm{m}$; in Figs 33, $34=10 \mu \mathrm{m}$. Figs 35-37: mature meronts (me), macrogamont (ma) and young oocyst (O). Figs 38, 39: zygotes (Z) on stalk-like extension of host epithelial cell (h), and a mature microgamont (Mi). Bar in Fig. 39 $=10 \mu \mathrm{m}$ and applies to Figs 35-38; h: host cell; hen: host cell nucleus 
Type locality: open, sandy country near Capanema, State of Pará, North Brazil

Prevalence: of 42 animals examined, 15 (35.7\%) were infected. Eight of these had concommitant infection with $A$.

cnemidophori

Pathology: no pathological effects noted in any of the infections studied

Etymology: the specific name paraensis is derived from

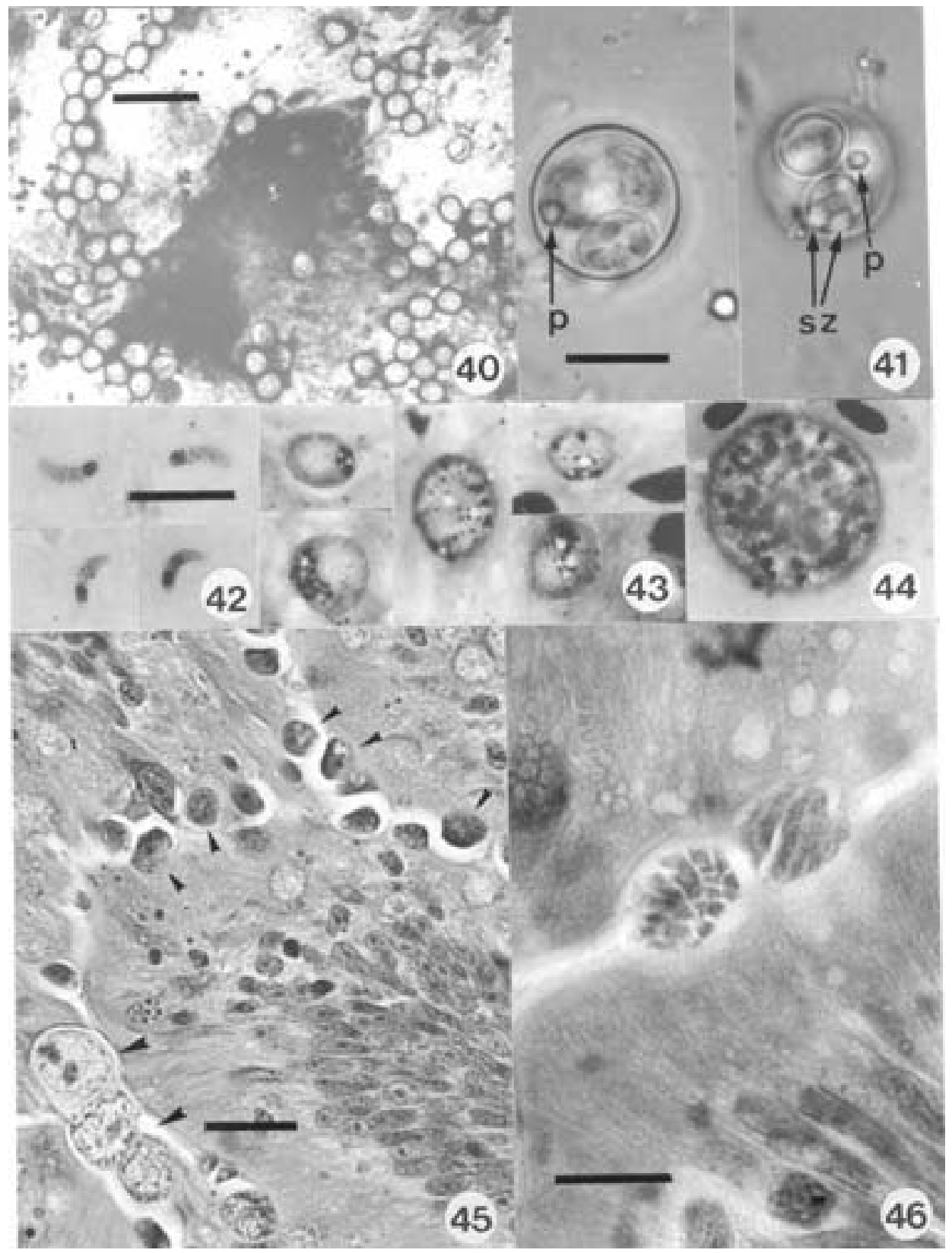

Figs 40-41: Acroeimeria cnemidophori in the lizard Cnemidophorus lemniscatus lemniscatus. Fig. 40: low power view of Giemsa-stained smear of ileum, showing vast number of oocysts; bar $=50 \mu \mathrm{m}$. Fig. 41 : mature oocysts in faeces; bar $=10 \mu \mathrm{m}$; p: polar body; sz: sporozoites in end-on view. Figs 42-46: A. paraensis n.sp. in C. l. lemniscatus. Fig. 42: merozoites. Fig. 43: young macrogamonts, showing vacuoles and associated precursers of wall-forming bodies. Fig. 44: nearly mature macrogamont with large wall-forming bodies; bar $=10 \mu \mathrm{m}$. Fig. 45: section of ileum, showing layer of developing and mature parasites (arrow-heads) on epithelium surface; bar $=10 \mu \mathrm{m}$. Fig. 46: two segmented meronts on the surface of the gut epithelium; Carnoy/Giemsa; bar $=10 \mu \mathrm{m}$ 
the State of Pará, where the type material was obtained Type material: stained smears and sections of the endogenous stages held in the author's collection in the Parasitology Department, Instituto Evandro Chagas. Reference number 1854.

\section{DISCUSSION}

It is considered unlikely that the same species of coccidia occur in hosts belonging to different families (Lainson \& Paperna 1999a), and in this respect it is interesting to note that Carini (1941) failed to infect the iguanid lizard Tropidurus torquatus with oocysts of $A$. cnemidophori from the teiid C. l. lemniscatus. A comparison of the parasites described in the present paper is limited, therefore, to previously described tetrasporocystic, dizoic coccidia with spherical/ subspherical oocysts in lizards of the family Teiidae.

The author (Lainson 1968) gave the name of E. ameivae to Eimeria-like oocysts in the faeces of the lizard $A$. undulata from Belize (ex British Honduras), Central America. In the absence of information on the endogenous stages, however, the generic status of the parasite now remains in doubt. Morphology of the mature oocysts and sporocysts

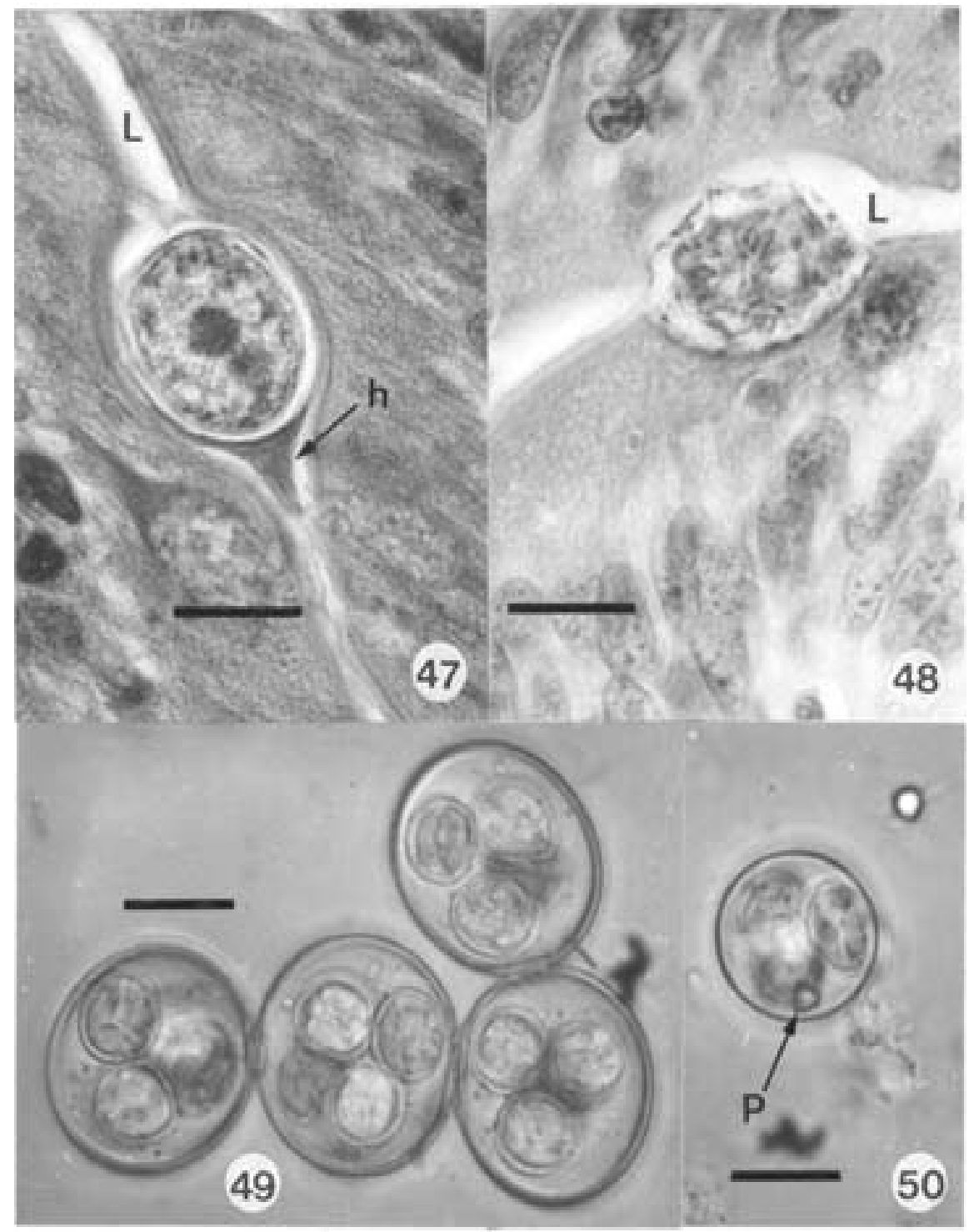

Figs 47-49: Acroeimeria paraensis n.sp. in the lizard Cnemidophorus lemniscatus lemniscatus. Fig. 47: zygote or young oocyst on epithelial surface of the ileum. Carnoy-fixed, Giemsa-stained section; h: remnants of host cell; L: gut lumen; Fig. 48: mature microgamont in same section; bar $=10 \mu \mathrm{m}$. Fig. 49: mature oocysts in faeces: note scattered granules and no polar body. Fig. 50: mature oocyst of $A$. cnemidopheri, in the same lizard, for comparison. Note conspicuous polar body (p); bar $=10 \mu \mathrm{m}$ 
is remarkably similar to that of $E$. carmelinoi n.sp., described here from the Brazilian teiid K. calcarata; namely $21.8 \times 20$ versus $21.2 \times 20.1$ and $9.5 \times 9.5$ versus $10.1 \times 9$ respectively. The only notable difference in the two descriptions is the presence of small, dispersed granules in the oocysts of $E$. carmelinoi n.sp., which were not noted in those of $E$. ameivae. In view of the difference in lizard hosts, and the wide geographic separation (the genus Kentropyx is restricted to South America, east of the Andes), however, it seems best to retain the two specific names until more material can be examined from Belize, in particular the endogenous stages of $E$. ameivae.
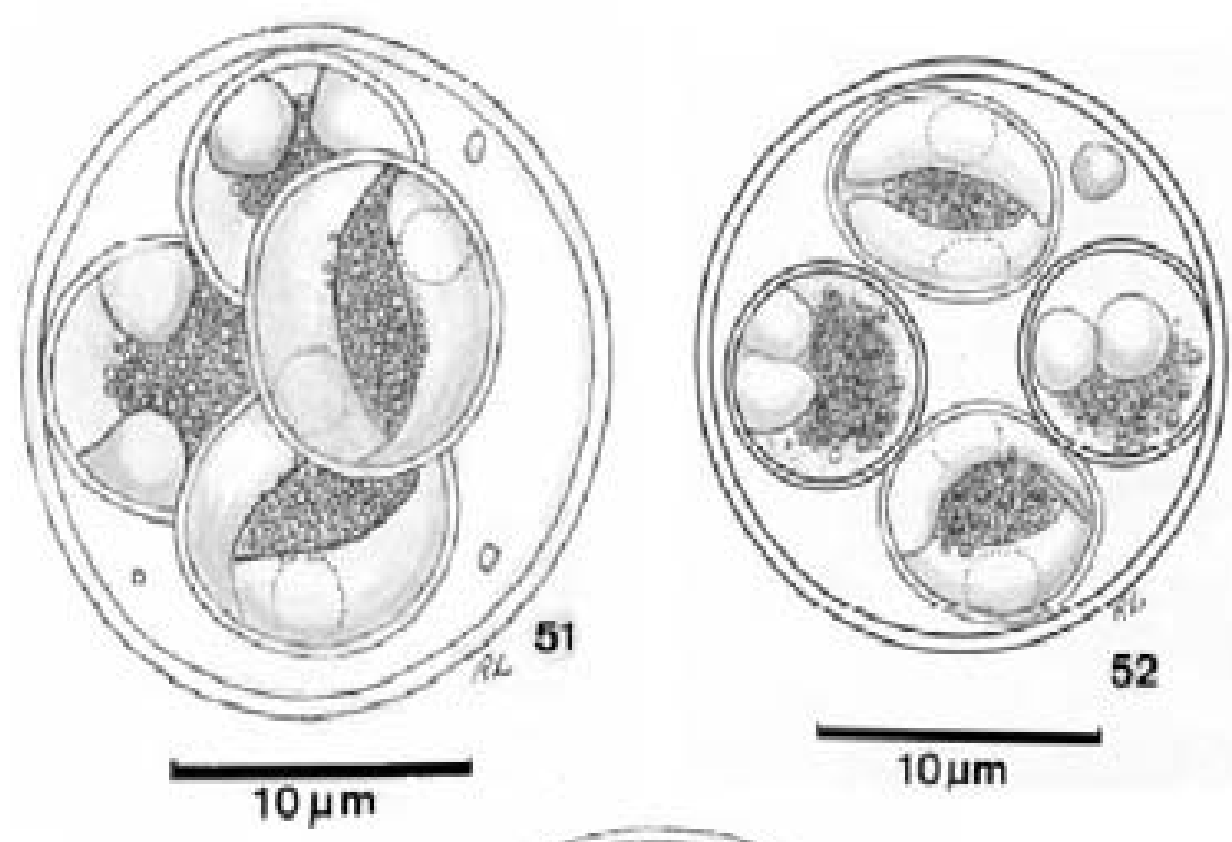

\section{$10 \mu \mathrm{m}$}

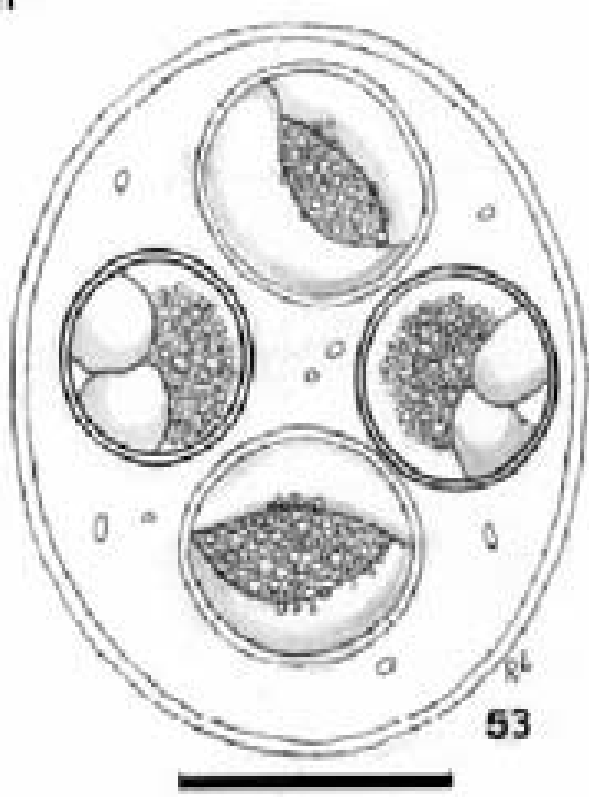

10 um

Figs 51-53: some intestinal coccidians of Brazilian lizards. Fig. 51: line-drawing of mature oocyst of Eimeria carmelinoi n.sp. from the lizard Kentropyx calcarata. Figs 52, 53: mature oocysts of Acroeimeria cnemidophori (Carini 1941) nov.comb., and A. paraensis n.sp., from the lizard Cnemidophorus lemniscatus lemniscatus 
The oocysts of $A$. cnemidophori, as re-described in the present paper, are very similar in size and morphology to those of a parasite recently described as A. pintoi in A. ameiva by Lainson and Paperna (1999a), the measurements being $18.4 \times 17.6$ versus $18 \times 17$ for oocysts and 8.1 x 7.3 versus $7.8 \times 7.3$ for sporocysts, respectively. The latter are devoid of Stieda bodies in both cases, and the only minor difference is that the oocysts of $A$. cnemidophori occasionally possess a single polar body, whereas those of $A$. pinto $i$ were described as sometimes containing "...a few small, scattered granules": there are no significant differences in their endogenous development. The author is led to the conclusion that $A$. pintoi is a synonym for A. cnemidophori (Carini 1941). A. ameiva and C.l. lemniscatus are both sun-loving, burrowing teiid lizards which share the same habitat. It comes as no surprise, therefore, that they should both be hosts of $A$. cnemidophori. Cross-infection experiments are now needed for final confirmation.

A. paraensis n.sp., differs from A. cnemidophori in its larger oocysts ( 24.4 x 21.8 versus 18.4 x 17.6) and sporocysts $(9 \times 8$ versus $8.1 \times 7.3)$; its oocysts tend to be more broadly ellipsoidal than those of $A$. cnemidophori, with a shape-index range of 1-1.2 compared with 1-1.1. They contain a small number of fine granules but, apparently, no polar body.

Arcay de Pereza (1963) described a coccidian in the gall-bladder epithelium of C. l. lemniscatus from Venezuela. The cylindrical tetrasporocystic, dizoic oocysts and rounded "operculated" (bi-valved?) sporocysts were so similar to those of E. flaviviridis Setna \& Bana, 1935 from the gall-bladder of the Indian gecko $H$. flaviviridis, that she gave the Venezuelan parasite subspecific status as $E$. flaviviridis americana. Later, Levine (1980) renamed the parasite E. perazae. This coccidian would appear to be uncommon, at least in the present area of study in Brazil, where no infections were detected in any of the $C . l$. lemniscatus examined. From morphology of the oocysts and sporocysts, and site of development, the parasite most probably belongs to the genus Choleoeimeria.

In conclusion, while it is appreciated that it is not always possible to autopsy infected animals, there is no doubt regarding the value of a combined study of both oocyst morphology and the endogenous stages of eimeriids in determining their taxonomic relationships, in particular those intestinal parasites of reptiles which produce very similar Eimeria-like oocysts.

\section{ACKNOWLEDGEMENTS}

To Constância M Franco, Manoel C de Souza and Antonio J de Oliveira Monteiro for technical assistance. Walter M Campos prepared the histological sections.

\section{REFERENCES}

Aquino-Shuster AL, Duszynski DW, Snell HL 1990. Three new coccidia (Apicomplexa) from the Hood Island lizard, Tropidurus delanonis, from the Galapagos archipelago. $J$ Parasitol 76: 313-318.

Arcay de Pereza L 1963. Studies on two new coccidia from the Venezuelan lizard Cnemidophorus lemniscatus lemniscatus: Hoarella garnhami gen.nov., sp.nov. and Eimeria flaviviridis americana subsp.nov. Parasitology 53: 95-107.

Bovee EC, Telford SR 1965. Eimeria sceloporis and Eimeria molochis spp.n. from lizards. J Parasitol 51: 85-94.

Carini A 1941. Sobre um plasmodio endoglobular e uma eimeria do lagarto Cnemidophorus lemniscatus lemniscatus. Arch Biol São Paulo 25: 205-208.

Carini A, Pinto C 1926. Estudos sobre coccideas. Arch Biol São Paulo 11: 83-86.

Dubey JP 1977. Toxoplasma, Hammondia, Besnoitia, Sarcocystis, and other tissue cyst-forming coccidia of man and animals. In JP Kreier, Parasitic Protozoa, Vol. III, Academic Press, Inc., New York, p. 101-237.

Finkelman S, Paperna I 1994. The endogenous development of 3 new intranuclear species of Isospora (Apicomplexa: Eimeriidae) from agamid lizards. Syst Parasitol 27: 213-226.

Hoare CA 1956. Classification of coccidia Eimeriidae in a "Periodic System" of homologous genera. Rev Bras Malariol 8: 197-202.

Lainson R 1968. Parasitological studies in British Honduras IV - Some coccidial parasites of reptiles. Ann Trop Med Parasitol 62: 260-266.

Lainson R, Paperna I 1999a. Some coccidia from the gallbladder and intestine of the teiid lizard Ameiva ameiva ameiva and the gecko Hemidactylus mabouia in North Brazil. Parasite 6: 151-162.

Lainson R, Paperna I 1999b. Re-descriptions of Isospora ameivae Carini, 1932 in the teiid lizard Ameiva ameiva and Isospora hemidactyli Carini, 1936 in the gecko Hemidactylus mabouia, with particular reference to their endogenous stages. Mem Inst Oswaldo Cruz 94: 459-466.

Levine ND 1973. Introduction, history, and taxonomy. In DM Hammond, PL Long (eds), The Coccidia, University Park Press, Baltimore, p. 1-22.

Levine ND 1980. Some corrections of coccidian (Apicomplexa: Eimeriidae) nomenclature. J Parasitol 66: 830-834.

Levine ND 1988. The Protozoan Phylum Apicomplexa, Vol. I, CRC Press Inc., Boca Raton, Fl, p.139-178.

McAllister CT, Upton SJ, Freed PS 1988. Eimeria lineri n.sp. (Apicomplexa: Eimeriidae) from the mediterranean gecko Hemidactylus turcicus (Sauria: Gekkonidae) in Louisiana and Texas. Proc Helm Soc Wash 55: 256-259.

Paperna I, Lainson R 1999. Fine structure of the epicytoplasmic eimerid coccidium Acroeimeria pintoi Lainson \& Paperna, 1999, a gut parasite of the lizard Ameiva ameiva in North Brazil. Parasite 6: 359-364.

Paperna I, Landsberg JH 1989. Description and taxonomic discussion of eimerian coccidia from African and Levantine geckoes. S Afr J Zool 24: 345-355. 